\title{
Growth Response of Two Species of Zizyphus to Inoculation with Arbuscular Mycorrhizal Fungi
}

\author{
A. A. Al-Qarawi and T. S. Alshahrani \\ Department of Plant Production, College of Food and Agricultural \\ Sciences, King Saud University, Riyadh, Saudi Arabia \\ Email: alqarawi@ksu.edu.sa
}

\begin{abstract}
Responses of two Zizyphus species of (Zizyphus spinachristi L. and $Z$. nummularia Burm.f.) to inoculation with and without arbuscular mycorrhizal fungi were investigated in a greenhouse over a 12 weeks period. Mycorrhizal inoculation significantly increased the biomass, root development (volume, surface area, diameter and number of tips), and photosynthetic pigments of both species in comparison to non-mycorrhizal plants. Such increases were related to the intensity of mycorrhizal infection in the root. Z. spina-christi was found to be more dependent on mycorrhizal fungi for its growth than $Z$. nummularia. These findings indicate that mycorrhizal inoculation can be a suitable way (biofertilizer agents) to improve growth and root development of tropical Zizyphus plants, particularly in poor soils.
\end{abstract}

\section{Introduction}

Mycorrhizae represent a symbiotic association between beneficial soil fungi and plant roots (Smith and Read, 1997). This symbiosis is characterized by a bidirectional movement of nutrients, where carbon flows to the fungus, and inorganic nutrients move to the plants (AbdelFattah, 2001). This is largely due to external hyphae absorbing poorly mobile soil nutrients beyond the depletion zones, around roots and root hairs, and transporting them to root tissues of their host, leading to improved plant growth and reproduction (Abdel-Fattah, 1997; Olsen et al., 1999; and Okurowska, 2008).

\footnotetext{
${ }^{1}$ Corresponding author: Email: alqarawi@ksu.edu.sa
} 
Arbuscular mycorrhizal (AM) fungi are ubiquitous in natural ecosystems, associating with about $80 \%$ of the terrestrial plant species (Smith and Read, 1997, Agwa and Abdel-Fattah, 2002, Besserer et al., 2008 \& Wang and Shi, 2008). They are recognized as important, widespread components of most terrestrial ecosystems, benefiting plant establishment by enhancing plant nutrient acquisition, improving soil quality and increasing resistance to environmental stresses (Abdel-Fattah et al., 2002, Al-Qarawi, 2002, Al-Karaki et al., 2004, Andrade et al., 2008 \& Wang et al., 2008) and also playing an important role in plant biodiversity, ecosystem variability and productivity (Likar et al., 2008).

Zizyphus spina-christi is an important native species in Saudi Arabia. The genus belongs to the family Rhamnaceae, which includes 40 species. Z. spina-christi is an indigenous tree of the Arabian Peninsula; it grows wild throughout the country, but in high density in the Southern and South-western regions of Saudi Arabia (Said, 1986). Leaves of this species are a source of medicinal compounds used for managing several ailments by the indigenous population (Zoghet and Alsheikh, 1999 \& Weinges \& Schick, 1995). It is used for its cleaning properties and is a staple food for animals. The leaves contain flavonoids (Nawwar et al., 1984 and Gupta \& Mehta, 2000), saponin, alkaloids, and other potentially allelochemical substances that may be important in the interaction between $Z$. spina-christi and other plant species. Increased growth and yield of Zizyphus plants in the presence of arbuscular mycorrhizal infection has been attributed mainly to the enhanced uptake of soil nutrients like phosphorus (Guissou et al., 1998 \& 1999 \& Ba et al., 2001). Glomus constrictum Trappe significantly improved the biomass production and nutrient uptake of Zizyphus mauritiana grown in the field, as compared with non-mycorrhizal plants (Mathur and Vyas, 1995 and 1999; \& Kale and Dod, 2000).

Naturally, mycorrhizal fungi play a key role in the natural and agricultural ecosystems through major functions. However, little is known about the ecology and functional role of mycorrhizal fungi in woody plants in Saudi Arabia. The present investigation was therefore undertaken to study the effect of arbuscular mycorrhizal (AM) inoculation on the growth and root development of two species of Zizyphus (Z. spina-christi L. and Z. nummularia Burm.f.) grown under the greenhouse conditions. 


\section{Materials and Methods}

\section{Plant and Growth Conditions}

Seeds of Zizyphus spina-christi L. and Zizyphus nummularia Burm. plants were surface sterilized in Clorox $12^{\circ}$ for $15 \mathrm{~min}$, subsequently rinsed with sterilized water and left to germinate for 7 days in moist sterilized filter paper. Uniform seedlings were planted (one plant/ tube) into sterilized plastic tubes containing loamy soil collected from Durab farm, College of Food and Agricultural Sciences, King Saud University. Half of the tubes for each plant species containing soil were left without sterilization to serve as mycorrhizal treatments. The mycorrhizal inoculum consisted of spores of Glomus mosseae and Glomus monosporum (620 spores/ 100g). Each individual plant received $600 \mathrm{~g}$ inoculums for inoculation treatments. The mycorrhizal fungi were originally from Durab farm, Saudi Arabia and were identified by G. M. Abdel-Fattah, Applied Mycology Dep., King Saud University. The nonmycorrhizal treatment received filter leachates $(1 \mathrm{ml} / \mathrm{plant})$ of the mycorrhizal inoculum to provide mycorrhiza-associated microorganisms other than mycorrhizal propagules. The filtrate was passed through a 25$\mu \mathrm{m}$ sieve to remove spores of mycorrhizal fungi. All tubes were randomized in a growth chamber under controlled conditions $(280 \mu \mathrm{mol}$ $\mathrm{m}^{2} \mathrm{~s}^{-1}, 22 / 18{ }^{\circ} \mathrm{C}, 16 \mathrm{~h}$ photoperiod, $70-80 \%$ relative humidity). All plants received 10\% Hoagland solution minus phosphorus (Hoagland and Arnon, 1950). Ten plants for each treatment were harvested at 12 weeks after planting.

\section{Measurements}

Fresh and dry masses of shoots and roots were determined immediately after harvest. Also, the shoot height was measured. For each treatment, the whole root system was washed carefully in tap water to remove the adhering soil particles, and stained with salt. Root system (six replicate plants for each treatment) was gently spread on Scanner (UMAX, Astra $4000 \mathrm{U}$ ) for analysis of root morphology (length, diameter, volume and tips) by using WinRhizo software (Regent Instruments, Quebec, Canada). 


\section{Staining of Mycorrhizal Root}

Immediately after harvest, the root system was cut into small segments $(5-10 \mathrm{~mm})$. Randomly chosen root segments were cleared in $7 \%$ potassium hydroxide at $90{ }^{\circ} \mathrm{C}$ for $45 \mathrm{~min}$, stained with trypan blue in lactophenol (Phillips and Hayman, 1970) for $15 \mathrm{~min}$ at $90{ }^{\circ} \mathrm{C}$. The excess stain was removed by washing with tap water. Forty randomly selected root pieces were mounted on slides in lactoglycerol, squashed, and examined microscopically (Leitz Wetzlar, Germany).

\section{Estimation of Mycorrhizal Infection}

The levels of mycorrhizal infection were estimated by the method of Trouvelot et al. (1986), which calculates three parameters of infection, namely, frequency of root infection $(\mathrm{F})$, intensity of cortical root infection (M) and arbuscule frequency in roots (A).

\section{Estimation of Photosynthetic Pigments}

Plant photosynthetic pigments (chlorophyll a and chlorophyll b) were determined by the spectrophotometric method recommended by Porra et al. (1989). A known fresh weight of leaves was extracted in $5 \mathrm{ml}$ of dimethylformamide and left overnight in refrigerator. The filtered extract was measured against a blank of pure solvent at 2 wave lengths of 663.8 and 646.8 using Ultrospec $2000-\mathrm{UV} /$ Visible spectrophotometer. The contents of chlorophyll a and chlorophyll $b$ and total chlorophyll $(a+b)$ were calculated using the following formulae and expressed in nanomoles per milliliter:

$$
\begin{gathered}
\text { Chl } a=13.43 A^{663.8}-3.47 A^{646.8} \\
\text { Chl } b=22.90 A^{646.8}-5.38 A^{663.8} \\
\text { Chl } a+b=19.43 A^{646.8}-8.05 A^{663.8}
\end{gathered}
$$

Mycorrhizal dependency (MD) was calculated by the following equation: Values of mycorrhizal plants - values on non-mycorrhizal plants/ values on mycorrhizal plants $\times 100$.

\section{Experimental Design and Statistical Analysis}

A factorial experiment in completely randomized design was carried out, to study the effects of two mycorrhizal treatments on two species of Zizyphus (Z. spina-christi L. and Z. nummularia Burm.), four 
treatments were repeated 10 times, this comprising a total of 40 plastic tubes $(50 \mathrm{~cm} \times 5 \mathrm{~cm})$, which were distributed randomly in a greenhouse under controlled conditions. The obtained data were statistically analyzed using the analysis of variance procedures, then means were compared by the least significant difference (LSD) method according to El-Nakhlawy (2009) using the SAS (SAS, 2005).

\section{Results and Discussion}

\section{Growth Responses}

Mycorrhizal inoculation resulted in a significant increase in shoot height and dry mass of the two species of Zizyphus, as compared with equivalent non-inoculated control plants (Table 1). Such increases in these parameters were linked with the degree of mycorrhizal infection. In this connection, increases in shoot height, shoot dry weight and root dry weight in response to the beneficial effects of the mycorrhizal fungi were positively correlated $(\boldsymbol{r}=0.730,0.862$ and 0.669 respectively for $Z$. spina-christi, while $\boldsymbol{r}=0.988,0.903$ and 0.744 respectively for $Z$. nummularia) to the intensity of mycorrhizal infection (Table 2).

Zizyphus spina-christi and Z. nummularia are important native species in Saudi Arabia, and carry enough economic and medicinal importance. The present data show that, regardless of the type of species, mycorrhizal inoculation enhanced the growth of Zizyphus plants in comparison with non-mycorrhizal plants. Such increases in growth responses were related to the degree of mycorrhizal infection for each plant species. The most prominent contribution of these mycorrhizal fungi to plant growth is mainly due to the uptake of phosphorus and other elements by extraradical mycorrhizal hyphae and transferrance to the root tissues (Abdel-Fattah, 1997, Guissou et al., 1998, Mathur and Vyas, 1999 and Wang et al., 2008). Our observations agree with those of Guissou, et al. (1999) who found that infection of Zizyphus mauritiana by vesiculararbuscular mycorrhizal fungi resulted in a greater absorption of $\mathrm{P}$ and $\mathrm{N}$ as compared with non-mycorrhizal plants. Mathur and Vyas (1995) reported that Glomus deserticola improved the biomass production, nutrient uptake and acclimatization of the produced plantlets of Zizyphus mauritiana in pots under green house conditions. 
Table 1. Effect of mycorrhizal inoculation on growth responses and root morphology of two species of Zizyph uss. Values are the means $\pm \mathrm{SE}$.

\begin{tabular}{|l|c|c|c|c|c|}
\hline \multirow{2}{*}{ Growth parameters } & \multicolumn{2}{|c|}{ Z. spina-christi } & \multicolumn{2}{c|}{ Z. . nummularia } & LSD \\
\cline { 2 - 6 } & $\mathbf{- ~ M ~}$ & $+\mathbf{M}$ & $-\mathbf{M}$ & $+\mathbf{M}$ & $(0.05)$ \\
\hline Shoot dry weight $(\mathrm{g})$ & $0.258 \pm 0.013$ & $0.40 \pm 0.039$ & $0.079 \pm 0.007$ & $0.245 \pm 0.039$ & 0.094 \\
\hline Root dry weight $(\mathrm{g})$ & $0.181 \pm 0.009$ & $0.296 \pm 0.063$ & $0.098 \pm 0.022$ & $0.163 \pm 0.019$ & 0.115 \\
\hline Root / shoot ratio & $0.704 \pm 0.061$ & $0.724 \pm 0.083$ & $0.098 \pm 0.023$ & $0.163 \pm 0.019$ & 0.464 \\
\hline Shoot height $(\mathrm{cm})$ & $14.16 \pm 0.017$ & $18.50 \pm 2.02$ & $9.67 \pm 0.044$ & $17.67 \pm 0.441$ & 3.46 \\
\hline Number of root tips & $885 \pm 31.1$ & $2021 \pm 17.5$ & $247 \pm 47.0$ & $184 \pm 49.9$ & 219.8 \\
\hline Root volume $(\mathrm{ml})$ & $0.566 \pm 0.092$ & $0.980 \pm 0.140$ & $0.653 \pm 0.123$ & $0.587 \pm 0.092$ & 0.371 \\
\hline Root length $(\mathrm{cm})$ & $275 \pm 72.5$ & $543 \pm 32.9$ & $190 \pm 9.73$ & $203 \pm 46.2$ & 150.9 \\
\hline Root diameter $\left(\mathrm{cm}^{2}\right)$ & $0.499 \pm 0.027$ & $0.459 \pm 0.018$ & $0.656 \pm 0.077$ & $0.614 \pm 0.019$ & 0.140 \\
\hline Root surface area $\left(\mathrm{cm}^{2}\right)$ & $45.4 \pm 11.0$ & $83.83 \pm 7.94$ & $38.64 \pm 7.46$ & $39.00 \pm 3.57$ & 25.9 \\
\hline
\end{tabular}

-M, non-mycorrhizal treatments, $+\mathrm{M}$, mycorrhizal treatments

Root dimenstions (length, diameter, volume, surface area and tips) of mycorrhizal Z. spina-christi were significantly larger than those of nonmycorrhizal plants. This increase in root parameters in response to mycorrhizal effects was positively correlated $(\boldsymbol{r}=0.860$ for length, 0.776 for volume and 0.877 for tips, Table 2) to the degree of mycorrhizal infection. On the other hand, there were no significant differences in root parameters between mycorrhizal and non-mycorrhizal $Z$. nummularia plants (Table 1).

Table 2. Values of correlations coefficients $(r)$ between intensity of mycorrhizal infection (M \%) and mycorrhizal dependency (MD) ${ }^{1}$ for several parameters of two species of Zizyphus.

\begin{tabular}{|l|c|c|}
\hline \multirow{2}{*}{ Parameters } & \multicolumn{2}{|c|}{$r$} \\
\cline { 2 - 3 } & Z. spina-christi & Z. . nummularia \\
\hline Shoot dry weight & $0.862^{* *}$ & $0.903^{* *}$ \\
\hline Root dry weight & $0.669^{*}$ & $0.744^{* *}$ \\
\hline Shoot height & $0.730^{* *}$ & $0.988^{* *}$ \\
\hline Number of root tips & $0.877^{* *}$ & -0.416 \\
\hline Root length & $0.860^{* *}$ & 0.130 \\
\hline Root volume & $0.776^{* *}$ & $0.687^{*}$ \\
\hline Chlorophyll a & $0.986^{* *}$ & $0.917^{* *}$ \\
\hline Chlorophyll b & $0.939^{* *}$ & $0.733^{* *}$ \\
\hline Total chlorophyll & $0.983^{* *}$ & $0.904^{* *}$ \\
\hline
\end{tabular}

$* P=0.05, * * P=0.01$

$(M D)^{1}=(M-N M) / N M \times 100$, where $M$ is parameter value of mycorrhizal plants and NM is parameter value of non-mycorrhizal plants. 
It is evident from the present study that root characters (total length, volume, diameter, surface area and tips) were greatly increased with inoculation by mycorrhizal fungi, compared with non-mycorrhizal treatments particularly in Zizyphus spina-christi plants. In another study, the density and length of root hairs of Z. mauritiana were positively correlated to mycorrhizal dependency (Guissou et al., 1998). These results substantiate the earlier observations that stimulation of root system is enhanced by VA-mycorrhizal infection (Khudairi, 1969, Bagayoko et al., 2000, Abdel-Fattah, 2001 \& Bernatchez et al., 2008). No significant difference was observed in the root to shoot dry mass ratio between mycorrhizal and non-mycorrhizal Z. spina-christi plants (Table 1). In contrast, this ratio was significantly higher in mycorrhizal $Z$. nummularia than in the non-mycorrhizal plants.

\section{Photosynthetic Pigments}

The contents of photosynthetic pigments (chlorophyll $a$, chlorophyll $b$ and total chlorophyll $a+b$ ) in leaves of the two species of Zizyphus mycorrhizal plants were significantly $(p=0.05)$ greater than those in equivalent non-mycorrhizal plants (Fig. 1). Such increases of their content were related to the degree of mycorrhizal infection. The increase in total chlorophyll $(a+b)$ in response to mycorrhizal effects was positively correlated $(\boldsymbol{r}=0.983$ and 0.904 for two species of Zizyphus respectively, Fig. 1).

\section{Mycorrhizal Root Infection}

The levels of root infection by mycorrhizal fungi are expressed in Table 3, as frequency of mycorrhizal root infection ( $\mathrm{F} \%$ ), intensity of mycorrhizal infection in the root tissues $(\mathrm{M} \%)$ and rate of arbuscular formation in root segments (A \%). The first gives an estimate of the rate of fungal colonization from the sol and of growth within the root, the second indicates the extent of colonization by the mycorrhizal fungi relative to root growth, whereas the third illustrates the rate of arbuscular (site of nutrient exchange between fungus and host plant) development. The levels of mycorrhizal infection in stained root segments of Z. spinachristi were significantly higher than root segments of $Z$. nummularia. No mycorrhizal colonization was observed in non-mycorrhizal plants of two species. 


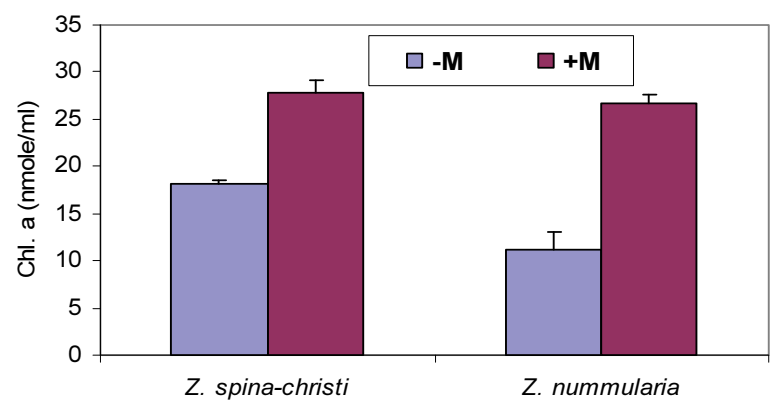

(A)

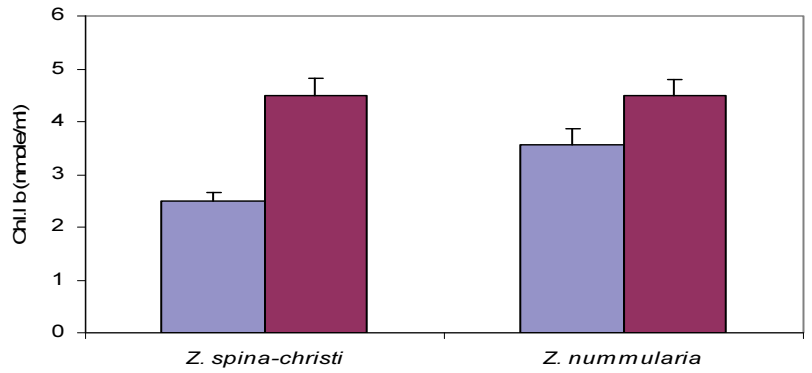

(B)

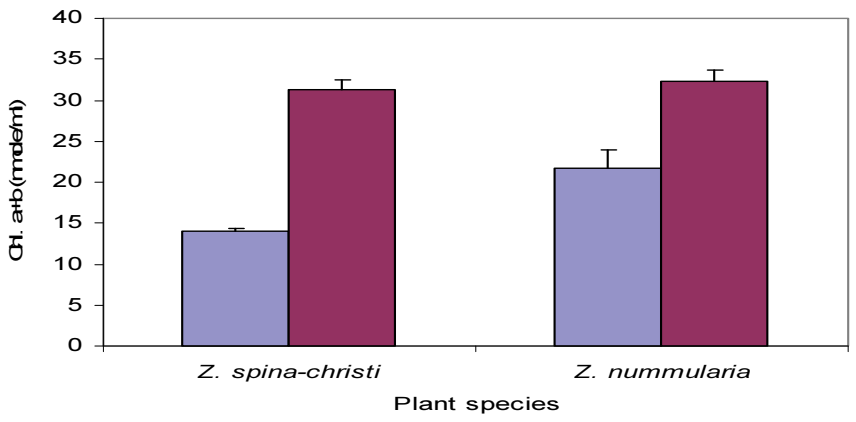

(C)

Fig. 1. Effect of mycorrhizal inoculation on the content of photosynthetic pigments $\{(A)$ chlorophyll a, (B) chlorophyll b and (C) total chlorophyll a $+b\}$ of two species of Zizyphus. Values are the means of three replicates. Error bars are SE. Where, -M: non - mycorrhizal treatments, +M: mycorrhizal treatments. 
Table 3. Levels of mycorrhizal infection of two species of Zizyphus. Values are the means \pm SE of three replicates.

\begin{tabular}{|l|c|c|c|c|}
\hline \multirow{2}{*}{ Parameters } & \multicolumn{2}{|c|}{ Z. spina-christi } & \multicolumn{2}{|c|}{ Z. nummularia } \\
\cline { 2 - 5 } & $-\mathbf{M}$ & $\mathbf{M}$ & $-\mathbf{M}$ & $+\mathbf{M}$ \\
\hline Frequency of mycorrhizal infection (F \%) & 0.0 & $68.33 \pm 7.26$ & 0.0 & $51.67 \pm 1.67$ \\
\hline Intensity of root cortical infection (M \%) & 0.0 & $5.18 \pm 1.52$ & 0.0 & $2.77 \pm 0.801$ \\
\hline Frequency of arbuscular development in roots (A \%) & 0.0 & $1.18 \pm 0.566$ & 0.0 & $0.460 \pm 0.111$ \\
\hline
\end{tabular}

$-\mathrm{M}$, non-mycorrhizal treatments, $+\mathrm{M}$, mycorrhizal treatments

\section{Mycorrhizal Dependency and Intensity of Infection}

Figure 2 shows that there was a close relation between mycorrhizal infection and the mycorrhizal dependency in the species studied.

In most cases, as the mycorrhizal infection increased, the rate of mycorrhizal dependency in plant growth and photosynthetic pigments was highly stimulated. In general, Z. spina-christi was greatly dependent on mycorrhizal fungi for the growth and development as compared with the Z. nummularia (Fig. 2).

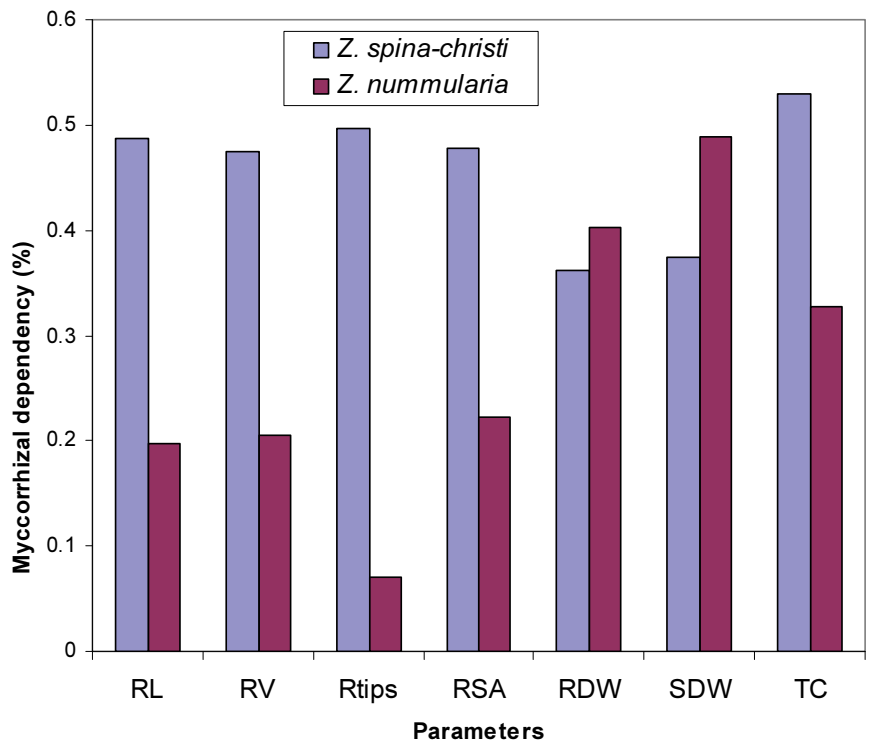

Fig. 2. Mycorrhizal dependency (MD \%) of two plant species of Zizyphus for their growth, where: RL (root length), RV (root volume), R tips (number of root tips), RSA (root surface area), RDW (root dry weight), SDW (shoot dry weight) and TC (total pigments). 


\section{Conclusion}

The results obtained here concluded that mycorrhizal inoculation can be a suitable way (biofertilizer agents) to improve growth and root development of tropical Zizyphus plants, particularly in poor soils. Farmers should be aware of the beneficial effects of mycorrhizae (biofertilizer agents) on plant growth and yield. Practical applications of these fungi are now possible, but these should bear in mind the factors (formulation, type of applications, viability of spores, ... etc) affecting mycorrhizal development and function. Further studies should be carried out in this field.

\section{References}

Abdel-Fattah, G.M. (1997) Functional activity of VA-mycorrhizal fungus (Glomus mosseae) in the growth and productivity of soybean plant growing in sterilized soil, Folia Microbiol., 5: 495-502.

Abdel-Fattah, G.M. (2001) Measurement of the viability of arbuscular mycorrhizal fungi using three different strains; relation to growth and metabolic activities of soybean plants, Microbiological Research, 156: 359-367.

Abdel-Fattah, G.M., Meghaed, F.F. and Ibrahim, A.H. (2002) Interactive effects of the endomycorrhizal fungus (Glomus etunicatum) and phosphorus fertilization on growth and metabolic activities of broad bean under drought stress, Pakis. J. Biol. Sci., 5: 853-861.

Agwa, H.E. and Abdel-Fattah, G.M. (2002) Arbuscular mycorrhizal fungi (Glomales) in Egypt. II- An ecological view of some deltaic Mediterranean coastal land, Acta Botanica Hungarica, 44: 1-17.

AL-Karaki, G.N., McMichael, B. and John, Z. (2004) Field response of wheat to arbuscular mycorrhizal fungi under drought stress, Mycorrhiza, 14: 263-269.

Al-Qarawi, A.A. (2002) Relationships Among Nitrogen Availability, Vesicular-Arbuscular Mycorrhizae, and Bromus tectorum in Disturbed Rangeland Sites in Colorado, Ph.D. Dissertation, Colorado State Univ. Fort Collins, CO. USA.

Andrade, S. A. L., da Silveira, A. P. D., Jorge, R. A. and de Abreu, M. F. (2008) Cadmium accumulation in sunflower plants influenced by arbuscular mycorrhiza, Internat. $J$. Phytoremediation, 10: 1-13.

Aseri, G. K., Jain, N., Panwar, J., Rao, A. V. and Meghwal, P. R. (2008) Biofertilizers improve plant growth, fruit yield, nutrition, metabolism and rhizosphere enzyme activities of pomergranate (Punica granatum L.) in Indian Thar Desert, Scientia Horti., 117: 130-135.

Azcon, R., Gomez, M. and Tobar, R. (1992) Effects of nitrogen sources on growth nutrition, photosynthetic rate and nitrogen metabolism of mycorrhizal and phosphorus-fertilized plants of Lactuca sativa L., New Phytol., 121: 227-231.

Ba, A. M., Plenchette, C., Danthu, P., Duponnois, R. and Guissou, T. (2001) Functional compatibility of two arbuscular mycorrhizae with thirteen fruit trees in Senegal, System. J., 50: $95-105$. 
Bagayoko, M., George, E., Romheld, V. and Buerkert, A. (2000) Effects of mycorrhizae and phosphorus on growth and nutrient uptake of millet, cowpea and sorghum on a west African soil, J. Agric. Sci., 135: 399-407.

Bernatchez, F., Jeannotte, R., Begg, C.B.M., Hamel, C. and Whalem, J.K. (2008) Soil fertility and arbuscular mycorrhizal fungi related to stress growing on small holder farms in Senegal, Journal of Arid Environments, 72: 1247-1256.

Besserer, A., Becard, G., Jauneau, A., Roux, C. and Sejalon-Delmas, N. (2008) GR24, a synthetic analog of strigolactones, stimulates the mitosis and growth of the arbuscular mycorrhizal fungus Gigaspora rosea by boosting its energy metabolism, Plant Physi., 148: 402-413.

El-Nakhlawy, F. S. (2009) Experimental Design and Analysis in Scientific Research. Scientific Pub. Center, KAU, Saudi Arabia, (Under Publication) In Arabic.

Guissou, T., Ba, A.M., Guinko, S., Duponnois, R. and Plenchette, C. (1999) Rock phosphate and vesicular-arbuscular mycorrhiza effects on growth and mineral nutrition of Zizyphus mauritiana Lam. in an alkaline soil, Ann. Sci. For., 55: 925-931.

Guissou, T., Ba, A. M., Ouadba, J.M., Guinko, S. and Duponnois, R. (1998) Responses of Parkia biglobosa (Jacq.) Benth, Tamarindus indica L. and Zizyphus mauritiana Lam. To arbuscular mycorrhizal fungi in a phosphorus-deficient sandy soil, Biol Fertil Soils, 28: 194198.

Gupta, N.K. and Mehta, A.K. (2000) Genetic variability and component characters for fruit yield in ber (Zizyphus mauritiana L.), Advanced Plant Sci., 13: 75-78.

Hoagland, D.R. and Arnon, D.I. (1950) The water-culture method for growing plants without soil, Cal. Agri. Expt. Sta. Circ., 347:1-32.

Jones, M.D. and Hutchinson, T.C. (1988) Nikel toxicity in mycorrhizal birch seedlings infected with Lactarius rufus or Scleroderm flavidum. II- Uptake of nickel, calcium, maganesium, phosphorus and iron, New Phytol., 108: 461-468.

Kale, V.S. and Dod, V.N. (2000) Effect of plant growth regulators on fruit characters and quality of ber (Zizyphus mauritiana L.), Crop Research Hisar., 20: 327-333.

Khudairi, A. K. (1969) Mycorrhizae in desert soils, Bioscience, 19: 598-599.

Likar, M., Bukovnik, U., Kreft, I., Chrungoo, N.K. and Regvar, M. (2008) Mycorrhizal status and diversity of fungal endophytes in roots of common buckwheat (Fagopyrum esculentum) and tartary buckwheat (F. tataricum), Mycorrhiza, 18: 309-315.

Mathur, N. and Vyas, A. (1995) In vitro, production of Glomus deserticola in association with Zizyphus mauritiana, Plant Cell Reports, 14: 735-737.

Mathur, N. and Vyas, A. (1999) Improved biomass production, nutrient uptake and establishment of in vitro raised Zizyphus mauritiana by VA mycorrhiza, Journal of Plant Physiology, 155: 129-132.

Nawwar, M.A., Ishak, M.S. and Michael, H.N. (1984) Flavonoids of Zizyphus spina-christi, Phytochem, 23: 2110-2111.

Okurowska, P. (2008) Effects of mycorrhizal colonization and fertilization on growth and photosynthesis of sweet basil under salt stress, J. Plant Nutrition, 31: 497-513.

Olsen, J.K., Scheafer, J.T., Edwards, D.G., Hunter, M.N., Galea, V.J. and Muller, L.M. (1999) Effects of a network of mycorrhizae on (Capsicum anmmum L.) grown in the field with five rates of applied phosphorus, Aust. J. Agric. Res., 50: 239-252.

Phillips, J.M. and Hayman, D.S. (1970) Improved procedures for clearing roots and staining parasitic vesicular-arbuscular mycorrhizal fungi for rapid assessment of infection, Trans. Br. Mycol. Soc., 55: 158-160. 
Porra, R.J., Thompson, W.A. and Kriedemann, P.E. (1989) Determination of accurate extinction coefficients and simultaneous equations for assaying chlorophylls a and b extracted with four different solvents: Verification of the concentration of chlorophyll standards by atomic absorption spectroscopy, Biochim. Biophys. Acta., 975: 384-394.

Said, A.E. (1986) Propagation of "Cidir" (Zizyphus spina-christi L) wild. I. seed germination, $J$. Coll. Agri., 8: 389-397.

SAS Institute Inc. (2005) SAS/STAT User's Guide, SAS Institute Inc, Cary, NC.

Smith, S.E. and Read, D.J. (1997) Mycorrhizal Symbiosis, Academic Press, London.

Trouvelot, A., Kough, J.L. and Gianinazzi-Pearson, V. (1986) "Mesure du taux de mycorrhization d'un systeme radiculaire recherché de methods d'estimation ayant une signification fonctionnelle, In: Gininazzi-Pearson, V. and Giainazzi, S. (eds). Physiological and Genetical Aspects of mycorrhiza". INRA Publications, Paris, pp: 217-221.

Wang, C.X., Li, X.L., Zhou, J.C., Wang, G.Q. and Dong, Y.Y. (2008) Effects of arbuscular mycorrhizal fungi on growth and yield of cucumber plants, Communication in Soil Science and Plant Analysis, 39: 499-509.

Wang, F.Y. and Shi, Z.Y. (2008) Biodiversity of arbuscular mycorrhizal fungi in China: a Review, Advances in Environmental Biology, 2: 31-39.

Weinges, K. and Schick, H. (1995) Dodeca acetyl prodelphinidin B3 from the dried leaves of Zizyphus spina-christi, Phytochemistry, 38: 505-507.

Zoghet, M. and Alsheikh, A. (1999) Wild Plants in the Region of Riyadh, King Saud Univ., Academic Publishing and Press, 234p. 


\section{استجابة نمو نوعين من نبات السدر لفطريات الجذور التكافلية الداخلية}

\section{عبد العزيز القرعاوي، و ثبيــث الثهراني \\ قسم الإنتاج النباتي - كلية علوم الأغذية و الزراعة - جامعة الملك سعود - الرياض - المدلكة الغربية السعودية}

المستخلص. ت تتاول هذا البحث دراسة اســتجابة نمــو و المحتــوى الصبغي لنوعين من نبات السدر في المملكة العربية السعودية لنأثير

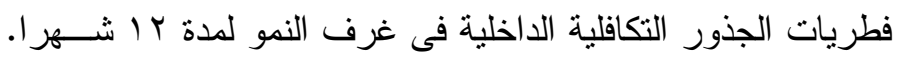
ونم التوصل إلى أن إصابة نباتات السدر بنوعية بفطريات الجذور فئهر

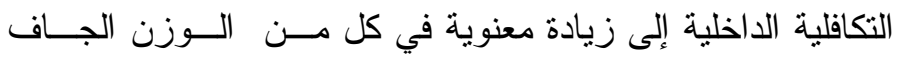

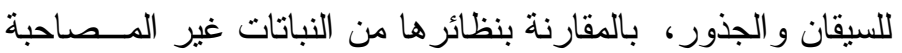

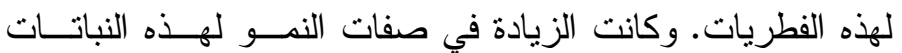

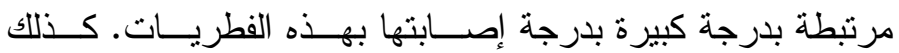
أوضحت الدراسة أن كلاً من حجم، ومساحة، وطول، وقة وقمم الجذور

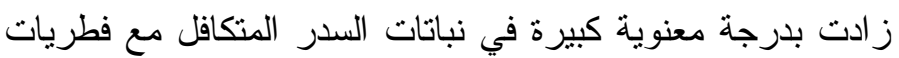

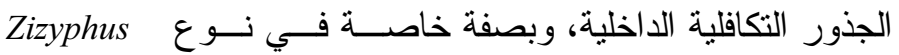
spina-christi

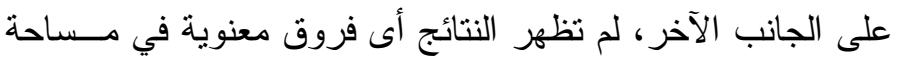

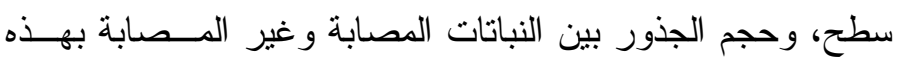

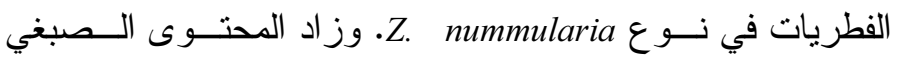
(الكلوروفيل أ ، ب) فى أوراق نباتات السدر بنوعيه معنويا، نتيجة الإصابة بفطريات الجذور التكافلية، مقارنة بالنباتات غير المصابة بهذه الفطريات. وكانت هذه الزيادات مرتبطة بدرجة كبيرة بدرجة 
إصابة النباتات بالفطريات. تؤكد النتائج التي تم التوصل إليهــا أن

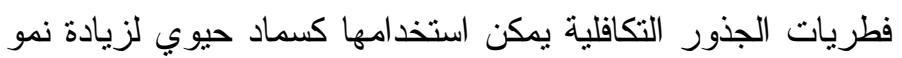
و إنتاجية نباتات السدر بنوعيه، وبصفة خاصة في التــرب الفقيــرة و التي تتعرض لظروف بيئية قاسية. 